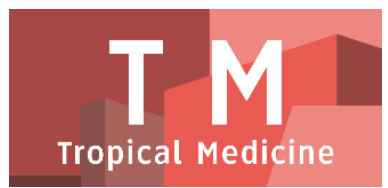

PAPER - OPEN ACCESS

\title{
Penambatan In Siliko Senyawa Ester Naringenin Sebagai Antidiabetes
}

\author{
Author : Nerdy Nerdy \\ DOI $\quad: 10.32734 / \mathrm{tm} . v 1 \mathrm{i} 1.83$ \\ Paper Page : $245-250$
}

Volume 1 Issue 1 - 2018 TALENTA Conference Series: Tropical Medicine (TM)

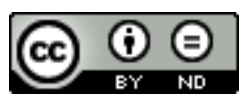

This work is licensed under a Creative Commons Attribution-NoDerivatives 4.0 International License.

Published under licence by TALENTA Publisher, Universitas Sumatera Utara
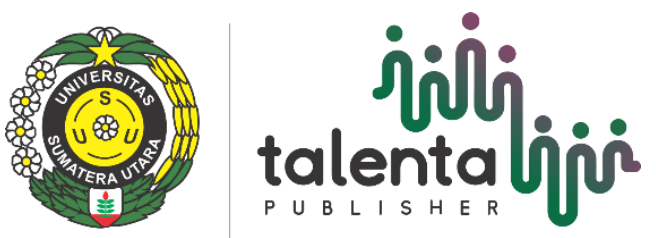


\title{
Penambatan In Siliko Senyawa Ester Naringenin Sebagai Antidiabetes
}

\author{
Nerdy ${ }^{\mathrm{a}, *}$, Effendy De Lux Putra ${ }^{\mathrm{b}}$, Ginda Haro ${ }^{\mathrm{c}}$, Urip Harahap ${ }^{\mathrm{d}}$ \\ ${ }^{a}$ Departemen Kimia Farmasi, Fakultas Farmasi, Universitas Sumatera Utara, Medan 20155, Indonesia \\ nerdy190690@gmail.com
}

\begin{abstract}
Abstrak
Diabetes melitus merupakan penyakit yang diderita oleh banyak orang di dunia. Banyak obat sintetik yang tersedia untuk pengobatan diabetes melitus. Namun, ada kebutuhan yang mendesak untuk menghasilkan obat antidiabetes yang lebih baik khususnya dari bahan alam. Literatur menunjukkan bahwa flavonoid merupakan metabolit sekunder dari tumbuhan yang berkhasiat sebagai antidiabetes yang baik. Naringenin merupakan flavonoid dari jeruk yang memiliki aktivitas antidiabetes. Senyawa turunan lipofilik dari flavonoid naringenin yang dalam bentuk ester dapat meningkatkan aktivitas antidiabetes dari senyawa induk. Tujuan penelitian ini adalah untuk menentukan aktivitas antidiabetes dari senyawa naringenin dan senyawa ester dari naringenin. Penelitian ini dilakukan dengan penambatan secara in siliko dari molekul senyawa uji naringenin, serta turunan ester dari naringenin dengan penambatan secara in siliko terhadap Phosphoenolpyruvate Carboxykinase (PEPCK) yang diunduh via Protein Data Bank (PDB) dengan kode protein 1KHB. Selanjutnya dilakukan proses penambatan dengan program PLANTS, dan kemudian dilakukan evaluasi nilai energi ikatan hasil proses penambatan. Proses penambatan kembali molekul ligan asli ke dalam molekul kantung ikatan Phosphoenolpyruvate Carboxykinase (PEPCK) diperoleh nilai Root Mean Square Deviation (RMSD) $0,7670 \AA$ A. Penambatan molekul senyawa uji senyawa turunan ester dari naringenin menunjukkan aktivitas yang lebih baik dengan nilai energi ikatan yang lebih rendah bila dibandingkan dengan senyawa induk naringenin.
\end{abstract}

Kata Kunci: Penambatan, In Siliko, Ester, Naringenin, Antidiabetes

\section{Pendahuluan}

Diabetes mellitus ditandai melalui hiperglikemia kronis dan gangguan metabolisme karbohidrat, lemak dan protein yang berhubungan dengan terjadinya kekurangan sekresi insulin atau aksi insulin baik secara mutlak maupun relatif [9]. Terapi insulin dan obat-obat hipoglikemik oral menawarkan kontrol glikemik yang efektif, tetapi terapi insulin memiliki kelemahan seperti ketidakefektifan dengan pemberian secara oral, waktu paruhnya singkat, kebutuhan akan pendinginan secara langsung, dan dapat terjadi hipoglikemia yang fatal pada kasus kelebihan dosis [2]. Oleh karena itu diperlukan pencarian suatu senyawa yang memiliki aktivitas antidiabetes yang digunakan secara oral. Penggunaan antidiabetes oral terbatas karena efek samping yang merugikan termasuk reaksi hematologikal, kutan dan gastrointestinal, koma, hipoglikemik dan gangguan fungsi hati dan ginjal. Zat-zat tersebut juga tidak tepat digunakan selama kehamilan [1].

Banyak tumbuh-tumbuhan dalam pengobatan herbal tradisional yang dipercaya mempunyai aktivitas hipoglikemik. Pustaka yang tersedia mengindikasikan bahwa terdapat lebih dari 800 spesies tumbuhan yang menunjukkan aktivitas hipoglikemik [8]. Organisasi kesehatan dunia merekomendasikan pengujian aktivitas tumbuh-tumbuhan di mana pengobatan yang aman sulit didapatkan [13]. Studi-studi terdahulu telah menunjukkan bahwa kandungan kimia yang diisolasi dari tumbuhan telah digunakan untuk pencegahan dan pengobatan kanker, 
penyakit jantung, diabetes mellitus, dan tekanan darah tinggi [12]. Flavonoid memiliki efek antioksidan yang tinggi. Beberapa penyakit kronis yang sering ditemui saat ini sebagian besar disebabkan oleh paparan terhadap radikal bebas yang berlebihan, diantaranya kerusakan ginjal, diabetes melitus, jantung koroner, hingga penyakit kanker [2].

Protein enzim Phosphoenolpyruvate Carboxykinase (PEPCK) memiliki ekspresi yang tinggi pada jaringan hati, ginjal, dan adiposa. Enzim Phosphoenolpyruvate Carboxykinase (PEPCK) merupakan enzim yang memegang peranan penting dalam proses glukoneogenesis hati, ginjal dan adiposa [11]. Sehingga berperan penting dalam homeostatis glukosa [7]. Protein enzim Phosphoenolpyruvate Carboxykinase (PEPCK) memiliki kontribusi dalam regulasi siklus trigliserida pada jaringan hati, ginjal dan adiposa, yang akan memicu diabetes melitus tipe 2, sehingga sangat penting untuk menghambat enzim Phosphoenolpyruvate Carboxykinase (PEPCK) pada penderita diabetes melitus tipe 2 [4]. Metformin bekerja dengan menghambat ekspresi gen protein enzim Phosphoenolpyruvate Carboxykinase (PEPCK)melalui jalur yang tidak tergantung insulin.

\section{Metode Panelitian}

Penelitian ini merupakan penelitian eksperimental untuk menguji pengaruh beberapa senyawa turunan ester (propionil, butiril dan valeril) dari naringenin terhadap aktivitas antikanker secara in siliko.

\subsection{Alat Dan Bahan}

Alat-alat yang digunakan pada penelitian ini adalah Alat-alat yang digunakan pada penelitian ini adalah seperangkat komputer Fujitsu T Series (T4310) yang dioperasikan dengan sistem Windows 7 Home Premium, prosesor Intel ${ }^{\circledR}$ Core ${ }^{\mathrm{TM}} 2$ Duo CPU T660, frekuensi $2.20 \mathrm{GHz}$, grafis 32-bit, kapasitas hard disk drive $320 \mathrm{~GB}$, dan kapasitas RAM memory 4.00 GB digunakan sebagai alat untuk menjalakan proses penambatan molekular; program Chem Draw Ultra digunakan sebagai media untuk memprediksikan koefisien partisi; program PLANTS digunakan sebagai media untuk menjalankan penambatan in siliko; program Yasara digunakan sebagai media untuk memvisualisasikan penambatan in siliko; program Co Pen Drive Linux KDE digunakan untuk menghubungkan Sistem Operasi Windows terhadap Sistem Operasi Linux; model dari struktur tiga dimensi enzim yang digunakan dalam penelitian ini adalah kantung ikatan Phosphoenolpyruvate Carboxykinase (PEPCK) dengan kode Protein Data Bank (PDB) adalah 1KHB diperoleh dari situs web http://www.rcsb.org/pdb; program Marvin Sketch digunakan sebagai media untuk menghasilkan model dua dimensi dan konformasi tiga dimensi dari molekul kimia

\subsection{Ekstraksi Ligan Asli dan Kantung Ikatan}

Kantung ikatan yang diperoleh dari Protein Data Bank merupakan gabungan antara ligan asli dengan kantung ikatan. Molekul ligan asli diekstraksi dari molekul kantung ikatan dengan bantuan program Yasara, sehingga diperoleh molekul ligan asli dan molekul kantung ikatan. Molekul ligan asli GCP berasal dari molekul kantung ikatan Phosphoenolpyruvate Carboxykinase (PEPCK) dengan kode protein 1KHB.

\subsection{Validasi Metode Penambatan In Siliko}

Molekul ligan asli dari masing-masing molekul kantung ikatan dibuat model dua dimensinya dan konformasi tiga dimensinya dengan program Marvin Sketch. Konformasi tiga dimensi dari masingmasing molekul ligan asli ditambatkan ke dalam molekul kantung ikatan asalnya, diperoleh nilai energi ikatan dari masing-masing konformasi. Konformasi yang memberikan nilai energi ikatan yang terendah dihitung kembali nilai Root Mean Square Deviation (RMSD) dengan membandingkan konformasi yang memberikan nilai energi ikatan terendah dengan konformasi awal dari ligan asli. Proses penambatan in siliko dinyatakan valid apabila diperoleh nilai Root Mean Square Deviation (RMSD) $<2 \AA$. Kantung ikatan yang memberikan hasil valid pada proses penambatan in siliko yang dapat digunakan untuk penambatan molekul senyawa uji secara in siliko. 


\subsection{Penambatan In Siliko Molekul Senyawa Uji}

Molekul senyawa uji dan senyawa pembanding dibuat model dua dimensinya dan konformasi tiga dimensinya dengan program Marvin Sketch. Konformasi tiga dimensi dari masing-masing molekul senyawa uji ditambatkan ke dalam berbagai kantung ikatan, diperoleh nilai energi ikatan dari masingmasing konformasi dari molekul senyawa uji pada berbagai kantung ikatan. Konformasi dari suatu molekul senyawa uji yang memberikan nilai energi ikatan yang terendah pada kantung ikatan tertentu kemudian akan dilakukan perbandingan dengan konformasi molekul senyawa uji yang lain yang juga memberikan nilai energi ikatan yang terendah pada kantung ikatan yang sama. Senyawa uji yang memberikan hasil yang terbaik pada pengujian dengan penambatan secara in siliko (nilai energi ikatan yang terendah) akan disintesis untuk dilanjutkan pengujian invitro.

\section{Hasil dan Pembahasan}

Kantung ikatan yang diperoleh dari Protein Data Bank dengan kode 1KHB merupakan gabungan antara molekul ligan asli GCP dengan molekul kantung ikatan Phosphoenolpyruvate Carboxykinase (PEPCK). Ligan asli GCP diekstraksi dari kantung ikatan Phosphoenolpyruvate Carboxykinase (PEPCK) dengan bantuan program Yasara, sehingga diperoleh molekul ligan asli GCP dan molekul kantung ikatan Phosphoenolpyruvate Carboxykinase (PEPCK). Gambar 1. menunjukkan secara tiga dimensi kombinasi molekul ligan asli GCP dan molekul kantung ikatan Phosphoenolpyruvate Carboxykinase (PEPCK) dan setelah diekstraksi.
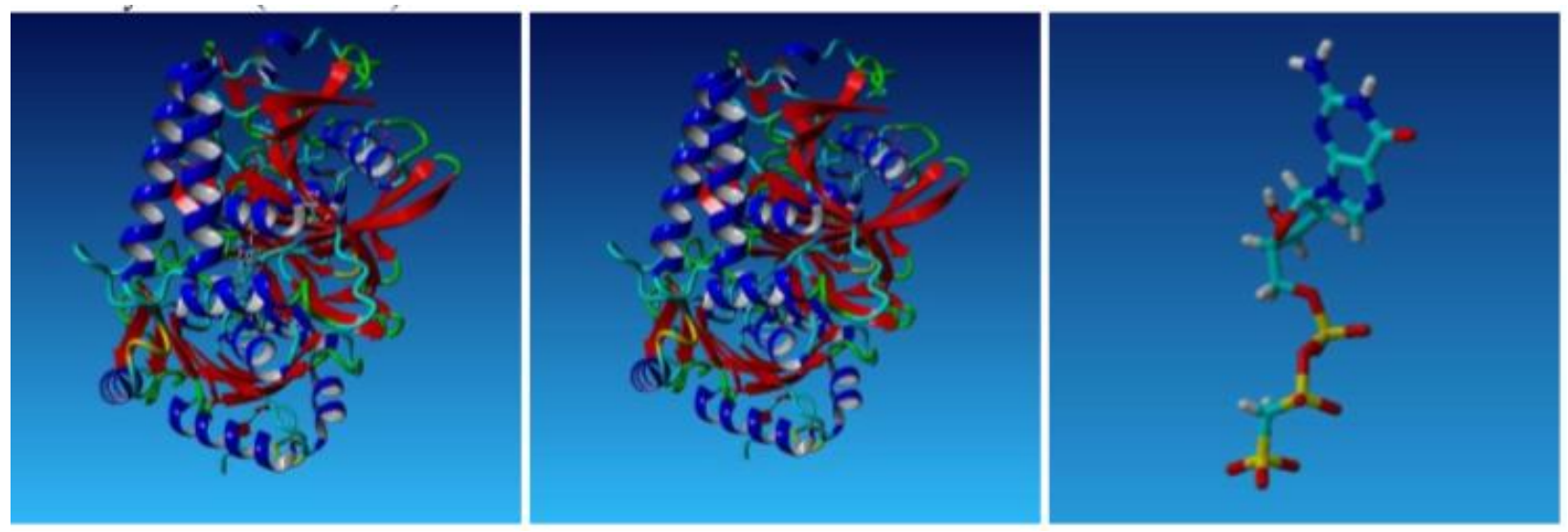

Fig. 1. Kombinasi molekul ligan asli GCP dan molekul kantung ikatan Phosphoenolpyruvate Carboxykinase (PEPCK) dan setelah diekstraksi

Molekul ligan asli GCP dibuat model dua dimensinya dan konformasi tiga dimensinya dengan program Marvin Sketch. Konformasi tiga dimensi dari molekul ligan asli GCP dalam berbagai konformasi ditambatkan kembali ke dalam molekul kantung ikatan Phosphoenolpyruvate Carboxykinase (PEPCK), diperoleh nilai energi ikatan dari masing-masing konformasi. Konformasi yang memberikan nilai energi ikatan yang terendah dihitung nilai Root Mean Square Deviation (RMSD). Proses perhitungan nilai Root Mean Square Deviation (RMSD) dilakukan dengan membandingkan konformasi yang memberikan nilai energi ikatan terendah dengan konformasi awal dari ligan asli.

Nilai Root Mean Square Deviation (RMSD) yang diperoleh adalah sebesar 0,7670 A. Proses penambatan in siliko pada molekul kantung ikatan Phosphoenolpyruvate Carboxykinase (PEPCK) ini dinyatakan valid, karena diperoleh nilai Root Mean Square Deviation (RMSD) < 2 A. Sehingga molekul kantung ikatan Phosphoenolpyruvate Carboxykinase (PEPCK) dapat digunakan untuk penambatan molekul senyawa uji secara in siliko. Gambar 2. menunjukkan secara tiga dimensi penambatan kembali molekul ligan asli GCP ke dalam molekul kantung ikatan Phosphoenolpyruvate Carboxykinase (PEPCK). 

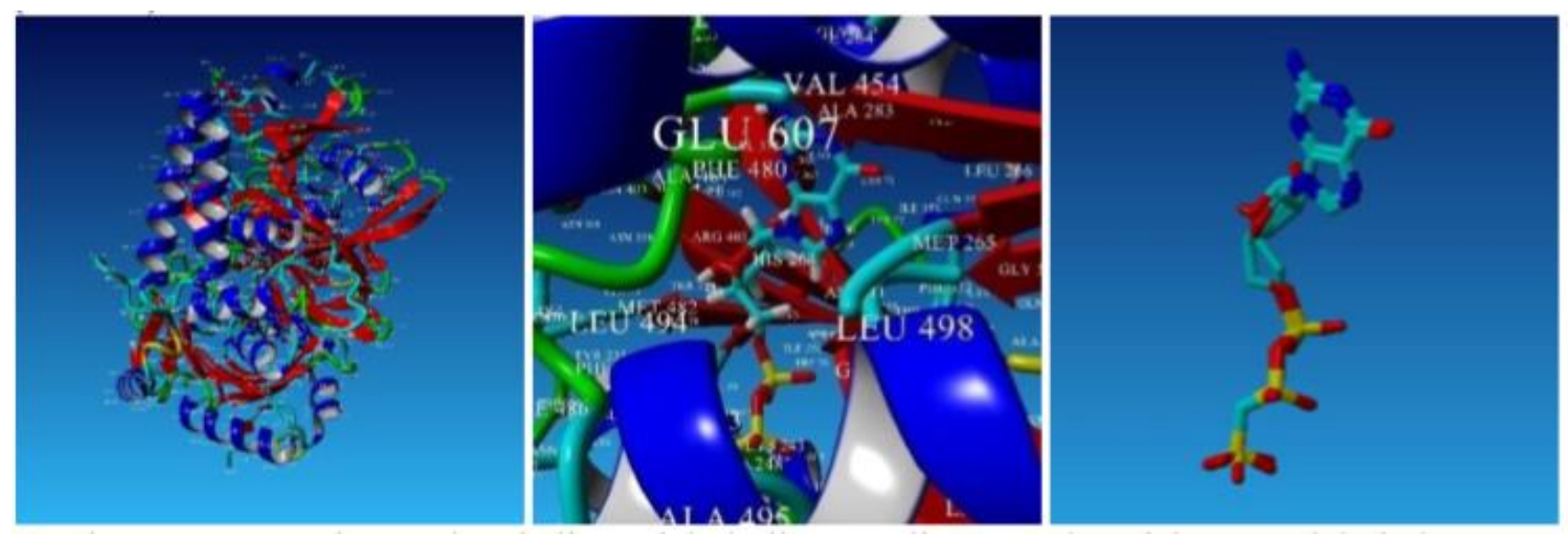

Fig. 2. Penambatan kembali molekul ligan asli GCP ke dalam molekul kantung ikatan Phosphoenolpyruvate Carboxykinase (PEPCK)

Molekul senyawa uji naringenin, beberapa senyawa ester (propionil, butiril dan valeril) turunan naringenin, serta molekul senyawa pembanding metformin dibuat model dua dimensinya dan konformasi tiga dimensinya dengan program Marvin Sketch. Konformasi tiga dimensi dari masingmasing molekul senyawa uji ditambatkan ke dalam kantung ikatan Phosphoenolpyruvate Carboxykinase (PEPCK), diperoleh nilai energi ikatan hasil penambatan secara in siliko dari masing-masing konformasi dari molekul senyawa uji pada berbagai kantung ikatan.

Konformasi dari suatu molekul senyawa uji yang memberikan nilai energi ikatan hasil penambatan secara in siliko yang terendah pada kantung ikatan Phosphoenolpyruvate Carboxykinase (PEPCK) dibandingkan dengan konformasi molekul senyawa uji yang lain yang memberikan nilai energi ikatan hasil penambatan secara in siliko yang terendah pada kantung ikatan yang sama. Tabel 1. menunjukkan tabulasi koefisien partisi serta penambatan in siliko molekul senyawa uji dan molekul senyawa pembanding pada kantung ikatan Phosphoenolpyruvate Carboxykinase (PEPCK).

Table. 1. Hasil Peningkatan Kadar Kolesterol Total Rata-rata pada Tikus Putih Jantan

\begin{tabular}{cccccc}
\hline Nomor & Nama & Rumus Molekul & $\begin{array}{c}\text { Panjang Rantai Atom } \\
\text { Karbon Ester }\end{array}$ & Koefisien Partisi & Energi Ikatan \\
\hline 1 & Naringenin & $\mathrm{C} 15 \mathrm{H} 12 \mathrm{O} 5$ & 0 & 1.63 & $-87,8117$ \\
2 & Naringenin Tripropionat & $\mathrm{C} 24 \mathrm{H} 24 \mathrm{O} 8$ & 3 & 3,52 & $-114,4260$ \\
3 & Naringenin Tributirat & $\mathrm{C} 27 \mathrm{H} 30 \mathrm{O} 8$ & 4 & 4,77 & $-115,4660$ \\
4 & Naringenin Trivalerat & $\mathrm{C} 30 \mathrm{H} 36 \mathrm{O} 8$ & 5 & 6.02 & $-109,4150$ \\
5 & Metmorfin & $\mathrm{C} 4 \mathrm{H} 11 \mathrm{~N} 5$ & - & 0,15 & $-64,6643$ \\
\hline
\end{tabular}

Hasil dari proses glukoneogenesis adalah dihasilkannya glukosa dari substrat karbon yang lebih kecil seperti laktat atau asam amino. Enzim Phosphoenolpyruvate Carboxykinase (PEPCK) merupakan enzim kunci untuk mengkonversikan oksaloasetat menjadi fosfoenolpiruvat yang dapat digunakan lebih lanjut dalam tahapan glukoneogenesis menghasilkan glukosa. Penghambatan enzim Phosphoenolpyruvate Carboxykinase (PEPCK) akan mengakibatkan penurunan kadar glukosa darah [3]. Obat antidiabetes turunan biguanida seperti metformin dan thiazolidinediones (troglitazone) dapat menghambat ekspresi gen atau enzim Phosphoenolpyruvate Carboxykinase (PEPCK). Metformin merupakan obat antidiabetes yang sering diresepkan dan telah dikenal baik dalam penghambatan enzim Phosphoenolpyruvate Carboxykinase (PEPCK) [10]. 
Molekul senyawa pembanding yang digunakan sebagai pembanding pada uji penghambatan terhadap molekul kantung ikatan Phosphoenolpyruvate Carboxykinase (PEPCK) adalah metformin. Molekul senyawa uji naringenin serta turunan ester dari naringenin memiliki nilai koefisien partisi yang lebih tinggi daripada molekul senyawa pembanding metformin. Berdasarkan data koefisien partisi maka naringenin serta turunan ester dari naringenin memiliki kemampuan yang lebih baik untuk menembus lapisan minyak atau lemak dari membran sel untuk mencapai ke dalam sel [6]. Gambar 3. menujukkan grafik perbandingan nilai energi ikatan hasil penambatan secara in siliko molekul senyawa uji terhadap molekul kantung ikatan Phosphoenolpyruvate Carboxykinase (PEPCK).

Nilai energi ikatan hasil penambatan secara in siliko merupakan afinitas ikatan antara senyawa uji (ligan) dengan

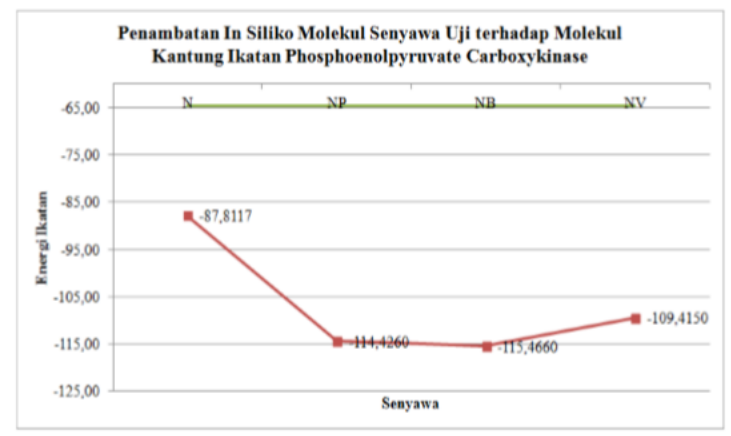

Fig. 3. Grafik perbandingan nilai energi ikatan hasil penambatan secara in siliko molekul senyawa uji terhadap molekul kantung ikatan Phosphoenolpyruvate Carboxykinase (PEPCK) Keterangan gambar : N $\rightarrow$ Naringenin; NP $\rightarrow$ Naringenin Tripropionat; NB $\rightarrow$ Naringenin $\mathrm{Tr}$

kantung ikatan. Semakin rendah nilai energi ikatan hasil penambatan secara in siliko, maka semakin kuat pula interaksi antara molekul senyawa uji (ligan) dan molekul kantung ikatan. Nilai energi ikatan hasil penambatan secara in siliko keseluruhan molekul senyawa uji naringenin serta turunan ester dari naringenin lebih rendah dibandingkan nilai energi ikatan hasil penambatan secara in siliko molekul senyawa pembanding metformin terhadap molekul kantung ikatan Phosphoenolpyruvate Carboxykinase (PEPCK). Hal ini berarti bahwa keseluruhan molekul senyawa uji naringenin serta turunan ester dari naringenin memiliki nilai interaksi yang lebih kuat dibandingkan molekul senyawa pembanding metformin terhadap molekul kantung ikatan Phosphoenolpyruvate Carboxykinase (PEPCK) [5].

\section{Kesimpulan}

Nilai Root Mean Square Deviation (RMSD) yang diperoleh pada proses penambatan kembali secara in siliko pada molekul kantung ikatan Phosphoenolpyruvate Carboxykinase (PEPCK) $<2 \AA$ dan proses penambatan ini dinyatakan valid sehingga dapat digunakan untuk penambatan molekul senyawa uji secara in siliko. senyawa turunan ester dari naringenin menunjukkan aktivitas yang lebih baik dengan nilai energi ikatan yang lebih rendah bila dibandingkan dengan senyawa induk naringenin.

\section{Referensi}

[1] Alarcon, F.J., Jimenez, M., Reyes, R., dan Romans, R. (2000). Hypoglycemic effect of extracts and fractions from Psacalium decompositum in healthy and alloxan diabetic mice. Journal of Ethnopharmacology. Vol 72 (2) : 21-27.

[2] Anuradha, K., Hota, D., dan Pandhi, P. (2001). Investigation of Central Mechanism of Insulin-Induced Hypoglycemic Convulsions in Mice. Indian Journal of Experimental Biology. Vol 39 (1) : 500502.

[3] Leithner, K. (2015). PEPCK in Cancer Cell Starvation. Oncoscience. Vol. 2 (10) : 805-806. 
[4] Millward, C.A., DeSantis, D., Hsieh, C.W., Heaney, J.D., Pisano, S., Olswang, Y., Reshef, L., Beidelschies, M., Puchowicz, M., and Croniger, C.M. (2010). Phosphoenolpyruvate Carboxykinase (PCK1) Helps Regulate the Triglyceride/Fatty Acid Cycle and Development of Insulin Resistance in Mice. Journal of Lipid Research. Vol. 51 (1) : 1452-1463

[5] Nerdy. (2015). In Silico Docking of Chemical Compounds from Roselle Calyces (Hibiscus Sabdariffa L.) as Antidiabetic. International Journal of Chemtech Research. Vol 8 (7) : 233 - 237.

[6] Onyekaba, T.C., Achilefu, C.C., dan Mbah, C.J. (2015). Partitioning Behavior of Gemifloxacin in Anionic, Cationic and Nonanionic Surfactants. Calculation of Dermal Permeability Coefficient. Pharmacology and Pharmacy. Vol 2015 (6) : 207-211.

[7] Panserat, S. Juan, E.P., Brèque, J., and Kaushik, S. (2001). Hepatic Phosphoenolpyruvate Carboxykinase Gene Expression is Not Repressed by Dietary Carbohydrates in Rainbow Trout (Oncorhynchus mykiss). The Journal of Experimental Biology. Vol. 204 (1) : $359-365$.

[8] Rajagopal, K., dan Sasikala, K. (2008). Antihyperglycaemic and antihyperlipidaemic effects of Nymphaea stellata in alloxan-induced diabetic rats. Singapore Medical Journal. Vol 49 (2) : 137141.

[9] Schoenfelder, T., Cirimbelli, T.M., dan Citadini, Z.V. (2006). Acute effect of Trema micrantha on serum glukosa levels in normal and diabetic rats. Journal of Ethnopharmacology. Vol 107 (3) : 456-459.

[10] Shih, C.C., Wu, J.B., Jian. J.Y., Lin, C.H., dan Ho, H.Y. (2015). Epicatechin-3-O- $\beta$-D-allopyranoside from Davallia formosana, Prevents Diabetes and Hyperlipidemia by Regulation of Glucose Transporter 4 and AMP-Activated Protein Kinase Phosphorylation in High-Fat-Fed Mice. International Journal of Molecular Sciences. Vol. 16 (1) : 24983-25001.

[11]Tontonoz, P., Hu, E., Devine, J., Beale, E.G., and Spiegelman, B.M. (1995). PPAR 2 Regulates Adipose Expression of the Phosphoenolpyruvate Carboxykinase Gene. Molecular and Cellular Biology. Vol. 15 (1) : 351-357.

[12] Waltner, M.E., Wang, X.L., Law, B.K. (2002). Epigallocatechin gallate, a constituent of green tea, represses hepatic glukosa production. Journal of Biological Chemistry. 277: 34933-34940.

[13] WHO. (1980). Second Report of the WHO Expert Committee on Diabetes Mellitus. Technical Report Series. Vol 646 (1) : 66. 